\title{
Production of Vinegar from Oil-palm Wine Using Acetobacter Aceti Isolated from Rotten Banana Fruits
}

\author{
Onuorah Samuel $^{1, *}$, Joson Lina $^{1}$, Obika Ifeanyi ${ }^{2}$ \\ ${ }^{1}$ Department of Applied Microbiology and Brewing, Nnamdi Azikiwe University, Nigeria \\ ${ }^{2}$ Department of Zoology, Nnamdi Azikiwe University, Nigeria
}

Copyright $(\subset 2016$ by authors, all rights reserved. Authors agree that this article remains permanently open access under the terms of the Creative Commons Attribution License 4.0 International License

\begin{abstract}
Vinegar production using Acetobacter aceti isolated from ten rotten banana fruits collected from different vendors in Eke-Awka Market in Awka, Nigeria was carried out using cultural techniques, with glucose yeast calcium carbonate-ethanol agar as the growth medium. The mean viable count of the bacterial isolates was $0.72 \times 10^{2} \mathrm{cfu} / \mathrm{g}$. The isolates were characterized on the basis of their morphological and biochemical characteristics and identified as Acetobacter aceti and Acetobacter orleanensis with mean counts of $0.53 \times 10^{2} \mathrm{cfu} / \mathrm{g}$ and $0.19 \times 10^{2} \mathrm{cfu} / \mathrm{g}$ respectively. Freshly-tapped oil-palm wine was allowed to ferment for seven days at $30^{\circ} \mathrm{C}$. The alcohol content was $10.0 \%$ while the $\mathrm{pH}$ value was 4.6 on the seventh day of the fermentation. The fermented palm wine was further fermented with the Acetobacter aceti for four weeks producing vinegar containing $7.1 \%$ acetic acid with a $\mathrm{pH}$ value of 3.5 . The Acetobacter aceti grew well in high concentration of alcohol indicating that it is suitable for large scale vinegar production. In addition, the rotten banana fruits regarded as wastes were converted into a useful raw material for the isolation of Acetobacter aceti needed for the production of acetic acid and vinegar.
\end{abstract}

Keywords Vinegar, Palm Wine, Acetobacter Aceti, Rotten Banana, Acetobacter Orleanensis Nigeria

\section{Introduction}

Vinegar, which is a good food preservative and a curing drink is the product of mixed fermentation by yeast followed by acetic acid bacteria [1]. It is a food additive that contains essential nutrients such as amino acids and is one of the oldest products of fermentation used by man [2]. It is a $4 \%$ acetic acid solution synthesized from sugary substances through alcoholic fermentation [3]. It is the acetic acid produced by the fermentation of alcohol which gives the characteristic flavor and aroma to vinegar.

The world consumption of vinegar was estimated to be worth almost two hundred and twenty million dollars [4]. However, levels of African vinegar production are difficult to estimate because of the black markets existing in most African countries and until recent years, most of the vinegar used was obtained mainly through the dilution of acetic acid of petrochemical origin.

In many African countries, the production of vinegar is being regulated by the government as new laws come into force [5]. These laws and regulation emphasize that vinegar destined for human use should be produced in a safe and biotechnological way through a double fermentation of agricultural products.

The raw material for vinegar production varies with the various types of vinegar [6] and from one locality to the other, thus, while wine made from grape is common in continental Europe and other growing countries, coconut water vinegar is common in Africa. The basic requirement for vinegar production is a raw material that will undergo an alcoholic fermentation such as apples, pears, grapes, honey, syrups, cereals, hydrolyzed starches, beer and wine [7].

Alcoholic fermentation of carbohydrate is the first step in the production of vinegar and it takes place under anaerobic condition. This step in which sugar is fermented to alcohol is completed by the action of yeast species. Kadere et al [8] highlighted acetic acid fermentation as the second stage in the production of vinegar and it is an aerobic process. This is the step in which alcohol is oxidized to acetic acid by the action of acetic acid bacteria such as Acetobacter aceti and Acetobacter schulzenbachi [9].

Acetobacter strains are the major acetic acid bacteria that are involved in vinegar production industrially [10]. Acetobacter aceti living in certain fruits and flowers are reported in beer and wine spoilage as well as fruit decay [11]. Acetobacter aceti is a gram-negative bacterium which is motile by peritrichous flagella, obligately aerobic, possessing only the ability for respiratory metabolism with no fermentation ability and does not form endospores [12]. This bacterium is ubiquitous in the environment, existing in soil, water, flowers, fruits on honey bees, in palm trees, palm wine and in essence wherever sugar fermentation is 
occurring.

Acetobacter aceti produces acetic acid from ethanol in alcoholic niches in the environment. Acetate and lactate are oxidized to carbondioxide and water by the organism. The optimal temperature for growth of the bacterium is between $25^{\circ} \mathrm{C}$ and $30^{\circ} \mathrm{C}$ and the $\mathrm{pH}$ optimum between 5.4 and 6.3 . Acetobacter aceti is a common contaminant in all industrial fermentation facilities. It is not a pathogen of humans, animals or plants. The potentials risks to human health or the environment associated with the use of this bacterium in fermentation facilities are low.

Acetobacter aceti can be isolated from various substrates such as rotten banana fruits which easily undergo spoilage and are usually discarded as wastes. The aim of this study is therefore to produce vinegar from palm wine using Acetobacter aceti isolated from rotten banana fruits. The result of this work will reveal if Acetobacter aceti isolated from rotten banana fruits could be used in producing vinegar. The use of this bacterium from the fruit for such production will be a means of converting rotten banana fruits to useful substrates for the industrial production of vinegar. Economic losses as well as the negative effect on the environment will also be drastically reduced.

\section{Materials and Methods}

\subsection{Samples Collection and Processing}

Ten samples of rotten banana fruits were obtained from different vendors at Eke-Awka Market, in Anambra State of Nigeria. One gram of each sample was homogenized in sterile distilled water and serially-diluted using a ten-fold dilution technique.

\subsection{Isolation of Bacteria}

$0.1 \mathrm{ml}$ of each serially-diluted sample $\left(10^{2}\right)$ was spread-plated on a plate of Glucose Yeast calcium carbonate-ethanol agar (GYC-EA) containing the antifungal agent ketoconazole at a concentration of $0.05 \mathrm{mg} / \mathrm{ml}$ and $3 \%$ ethanol. The composition of the medium was glucose (10\%), yeast extract $(1.0 \%)$, calcium carbonate $(2.0 \%)$, agar $(1.5 \%)$ and distilled water (1 litre). The plates were incubated in an inverted position at $30^{\circ} \mathrm{C}$ for 24 hours, after which the colonies that developed were counted and sub-cultured by streaking on nutrient agar plates to obtain pure cultures. The pure cultures were stored on GYC-EA slants and were used in characterizing and identifying the bacteria.

\subsection{Characterization and Identification of the Bacterial Isolates}

The strains were characterized and identified using colony morphological characteristics and biochemical tests. Gram staining, sugar (glucose, fructose, sucrose) fermentation, motility, methyl red, voges proskaeur, indole, oxidase, citrate utilization, nitrate reduction, urease, spore and catalase tests were carried out as done by Onuorah et al [13 ]. They were identified according to Holt et al [14].

\subsection{Production of Vinegar}

The Orleans method [15] otherwise known as the slow method was adopted in the production of vinegar.

\subsubsection{Alcoholic Fermentation}

One litre of freshly-tapped palm wine was purchased from a tapper at Amaokwe Udi in Udi Local Government Area of Enugu State and left to ferment at $30^{\circ} \mathrm{C}$ for seven days to convert the sugars to ethanol by the action of the yeasts present in the palm wine. The palm was decanted through a sterilized sac cloth at the end of the seven days fermentation to remove excess yeast and stop further fermentation. The decanted palm wine (must) was thereafter boiled for one hour, allowed to cool and introduced into a sterile bottle. The alcohol content and $\mathrm{pH}$ of the fermenting palm wine were monitored during the seven days of fermentation.

\subsubsection{Determination of $\mathrm{pH}$ of the Fermenting Palm Wine and Vinegar}

A $\mathrm{pH}$ meter (JENWAY) was used to measure the $\mathrm{pH}$ of the palm wine and vinegar during the fermentation. The meter was first standardized with buffers 4.0 and 7.0, after which its electrode was dipped into the samples and the $\mathrm{pH}$ values were read and recorded.

\subsubsection{Determination of the Alcohol Content of the Fermenting Palm Wine}

An alcohol meter was used to measure the alcohol content of the palm wine during fermentation. The meter was dipped into the fermenting palm wine and the alcohol content was read and recorded.

\subsubsection{Acetic Acid Fermentation}

One loopful of the isolated Acetobacter aceti was inoculated into the sterile bottle containing $250 \mathrm{ml}$ of the must. The bottle was thereafter covered with a sac cloth to prevent the entry of insects. The must was allowed to ferment for four weeks at $30^{\circ} \mathrm{C}$. At the end of the fermentation period, a thick film known as mother of vinegar had covered the surface of the must and was carefully scooped out to avoid contamination. The vinegar was thereafter filtered.

\subsubsection{Acetic Acid Assay of the Vinegar}

The assay of acetic acid was carried out every seven days after inoculation with Acetobacter aceti. 5mls of the vinegar were added to $20 \mathrm{ml}$ of distilled water in a $250 \mathrm{ml}$ conical flask and mixed with 5 drops of phenolphthalein. The mixture was titrated against $0.5 \mathrm{~N}$ sodium hydroxide till the appearance of pale pink colour in the flask. The volume of 
sodium hydroxide consumed during the titration was measured and the percentage of acetic acid in the vinegar was calculated using the formular

$$
\% \text { Acetic acid }=\frac{\text { Mass of Acetic Acid }}{\text { Mass of Vinegar }} \times 100
$$

\section{Results}

The viable count of the bacteria isolated from the rotten banana fruits are shown in Table 1 . The viable counts ranged between $0.63 \times 10^{2} \mathrm{cfu} / \mathrm{g}$ and $0.83 \times 10^{2} \mathrm{cfu} / \mathrm{g}$.

Table 1. Viable Count Of The Bacterial Isolates From The Rotten Banana fruits

\begin{tabular}{|c|c|}
\hline Samples & Viable Counts $\left(\mathrm{x} 10^{2} \mathrm{cfu} / \mathrm{g}\right)$ \\
\hline 1 & 0.63 \\
\hline 2 & 0.69 \\
\hline 3 & 0.72 \\
\hline 4 & 0.65 \\
\hline 5 & 0.80 \\
\hline 6 & 0.74 \\
\hline 7 & 0.68 \\
\hline 8 & 0.83 \\
\hline 9 & 0.76 \\
\hline 10 & 0.70 \\
\hline Mean & 0.72 \\
\hline
\end{tabular}

The viable counts of the Acetobacter aceti and Acetobacter orleanensis from the rotten banana fruits are shown in Table 2 . The counts were between $0.47 \times 10^{2}$ and $0.63 \times 10^{2} \mathrm{cfu} / \mathrm{g}$ for Acetobacter aceti and between $0.15 \times 10^{2}$ $\mathrm{cfu} / \mathrm{g}$ and $0.25 \times 10^{2} \mathrm{cfu} / \mathrm{g}$ for Acetobacter orleanensis.

Table 2. Viable Counts Of The Acetobacter aceti and Acetobacter orleanensis from the Rotten Banana Fruits $\left(\times 10^{2} \mathrm{cfu} / \mathrm{g}\right)$

\begin{tabular}{|c|c|c|}
\hline Samples & Acetobacter aceti & $\begin{array}{c}\text { Acetobacter } \\
\text { orleanensis }\end{array}$ \\
\hline 1 & 0.47 & 0.16 \\
\hline 2 & 0.48 & 0.21 \\
\hline 3 & 0.54 & 0.18 \\
\hline 4 & 0.50 & 0.15 \\
\hline 5 & 0.63 & 0.17 \\
\hline 6 & 0.49 & 0.25 \\
\hline 7 & 0.53 & 0.15 \\
\hline 8 & 0.60 & 0.23 \\
\hline 9 & 0.51 & 0.25 \\
\hline 10 & 0.55 & 0.25 \\
\hline Mean & 0.53 & 0.19 \\
\hline
\end{tabular}

The morphological and biochemical characteristics of the Acetobacter species from the rotten banana fruits are presented in Table 3. Acetobacter aceti were rod shaped, opaque, convex in elevation, smooth-surfaced and arranged in clusters, gram-negative, indole negative, spore negative, motile, catalase positive, did not utilize citrate, methyl red positive, voges proskaeur positive, nitrate reduction positive, oxidase negative, urease negative, fermented glucose, fructose and sucrose and produced clear zones that became cloudy while growing on glucose yeast calcium carbonate-ethanol medium while the Acetobacter orleanensis were rod-shaped, arranged in clusters, opaque, convex in elevation, smooth-surfaced, gram-negative, indole negative, motile, catalase positive, citrate negative, methyl red positive, voges proskaeur positive, nitrate reduction positive, oxidase negative, urease negative, fermented glucose, did not ferment fructose and sucrose and produced clear zones that did not become cloudy in the centre while growing on glucose yeast calcium carbonate-ethanol medium.

Table 3. Morphological and Biochemical Characteristics of the Bacterial Isolates From The Rotten Banana Fruits

\begin{tabular}{|c|c|c|}
\hline \multirow{2}{*}{$\begin{array}{c}\text { Characteristics } \\
\text { Shape }\end{array}$} & \multicolumn{2}{|c|}{ Results } \\
\hline & Rod & Rod \\
\hline Arrangement & Clusters & Clusters \\
\hline Opacity & Opaque & Opaque \\
\hline Elevation & Convex & Convex \\
\hline Surface & smooth & smooth \\
\hline Gram reaction & Negative & Negative \\
\hline Indole & Negative & Negative \\
\hline Motility & Positive & Positive \\
\hline Catalase & Positive & Positive \\
\hline Spore & Negative & Negative \\
\hline Citrate utilization & Negative & Negative \\
\hline Methyl red & Positive & Positive \\
\hline Voges proskaeur & Positive & Positive \\
\hline Nitrate reduction & Positive & Positive \\
\hline Oxidase & Negative & Negative \\
\hline Urease & Negative & Negative \\
\hline Glucose fermentation & Positive & Positive \\
\hline Sucrose fermentation & Positive & Negative \\
\hline Fructose fermentation & Positive & Negative \\
\hline $\begin{array}{l}\text { Growth on Glucose yeast } \\
\text { calcium carbonate-ethanol } \\
\text { medium }\end{array}$ & $\begin{array}{c}\text { Produced clear } \\
\text { zone that } \\
\text { became cloudy } \\
\text { in the centre }\end{array}$ & $\begin{array}{c}\text { Produced clear } \\
\text { zone that did not } \\
\text { become cloudy } \\
\text { in the centre }\end{array}$ \\
\hline Identity & $\begin{array}{c}\text { Acetobacter } \\
\text { aceti }\end{array}$ & $\begin{array}{l}\text { Acetobacter } \\
\text { orleanensis }\end{array}$ \\
\hline
\end{tabular}

The alcohol and $\mathrm{pH}$ levels of the fermenting palm wine are shown in Table 4. The alcohol levels were between $3.0 \%$ and $10.0 \%$ while the $\mathrm{pH}$ levels were between 4.6 and 6.9 . 
Table 4. Alcohol and $\mathrm{pH}$ Levels of the Fermenting Palm Wine

\begin{tabular}{|c|c|c|}
\hline Days of Fermentation & Alcohol Level (\%) & $\mathrm{pH}$ Level \\
\hline 1 & 3.0 & 6.9 \\
\hline 2 & 3.9 & 6.7 \\
\hline 3 & 4.3 & 6.1 \\
\hline 4 & 6.2 & 5.8 \\
\hline 5 & 7.0 & 5.4 \\
\hline 6 & 8.5 & 4.9 \\
\hline 7 & 10.0 & 4.6 \\
\hline
\end{tabular}

The aceti acid content and $\mathrm{pH}$ levels of the vinegar during fermentation are presented in Table 5. The acetic acid content was between $3.8 \%$ and $7.1 \%$ while the $\mathrm{pH}$ ranged between 3.5 and 4.4 .

Table 5. Acetic Acid Content and $\mathrm{pH}$ Levels of the Vinegar during Fermentation

\begin{tabular}{|c|c|c|}
\hline Weeks of Fermentation & Acetic Acid Content (\%) & $\mathrm{pH}$ Level \\
\hline 1 & 3.8 & 4.4 \\
\hline 2 & 4.5 & 4.2 \\
\hline 3 & 5.8 & 3.9 \\
\hline 4 & 7.1 & 3.5 \\
\hline
\end{tabular}

\section{Discussion}

The mean count of the bacterial isolates from the rotten banana fruits was $0.72 \times 10^{2} \mathrm{cfu} / \mathrm{g}$ (Table 1) while the mean counts of the Acetobacter aceti and Acetobacter orleanensis were $0.53 \times 10^{2} \mathrm{cfu} / \mathrm{g}$ and $0.19 \times 10^{2} \mathrm{cfu} / \mathrm{g}$ respectively (Table 2). This result indicated that Acetobacter aceti is the major acetic acid bacterium present in rotten banana fruits.

The bacteria were characterized on the basis of their morphological and biochemical characteristics and identified with the scheme of Holt et al [14]. The characteristics indicated that the isolates were Acetobacter aceti and Acetobacter orleanensis (Table 3). Hommel et al [11] reported that Acetobacter aceti can be isolated from various fruits such as plantain fruits. Acetobacter aceti is a gram-negative bacterium which is motile by peritrichous flagella and does no form endospores [12].

The alcohol content of the fermenting palm wine was the lowest on the first day of fermentation $(3.0 \%)$ but increased progressively as the days of fermentation increased, with the highest value of $10.0 \%$ on the seventh day of the fermentation (Table 4). This result indicated that palm wine produces high level of alcohol when allowed to ferment, thus making it a suitable substrate for vinegar production. The highest $\mathrm{pH}$ value of 6.9 was recorded on the first day of the fermentation of the palm wine. This value decreased as the days of the fermentation increased, with the lowest value of 4.6 obtained on the seventh day of the fermentation. This result is in agreement with the works of Okafor [16] and Faparusi and Bashir [17] who reported an increase in alcohol content and a decrease in $\mathrm{pH}$ level of palm wine during fermentation. The result also indicated that the low $\mathrm{pH}$ favoured alcohol production by the yeasts and inhibited the growth of contaminating microorganisms.

The acetic acid content of the vinegar was lowest (3.8\%) during the first week of fermentation of the alcohol with Acetobacter aceti but increased to $7.1 \%$ during the fourth week of fermentation (Table 5). In addition, the $\mathrm{pH}$ decreased progressively from 4.4 during the first week of fermentation of the alcohol to 3.5 during the fourth week of the fermentation. This result indicated that Acetobacter aceti has the ability to oxidize significant quantities of ethanol under the acidic conditions created by the presence of acetic acid and agreed with the work of Stanier [18] and Hickey Richard and Vaughn Reese [15].

Palm wine despite being a rich medium with high concentration of hexoses (200-250g/1), high pH (5.17-6.92) and titrable acidity $(2-10 \mathrm{~g} / \mathrm{l})$ as tartaric acid provides a highly selective medium for bacterial growth. In addition, the harsh environment of the fermenting palm wine created by high ethanol concentration, and low $\mathrm{pH}$ resulting from the consumption of sugars by yeasts during alcoholic fermentation restricted the growth of other bacterial species [19].

Acetobacter species are better adapted to higher ethanol concentrations and thus tend to colonize fermented palm wine, thereby causing the sour taste [20]. This work is in agreement with the study of Kocher et al [21] on the production of vinegar using Acetobacter aceti isolated from fruits in terms of the tolerance of the bacteria to high alcohol content and high production of acetic acid in vinegar.

The acetic acid content of the vinegar produced in this work conformed to the standard specified by the Standards Organization of Nigeria for acetic content of retailed vinegar (4\%-8\%), thus from the results obtained, rotten banana fruit is a potential substrate for the isolation of Acetobacter aceti for the production of acetic acid and wide varieties of vinegar.

\section{Conclusions}

The result of this work showed that Acetobacter aceti can be isolated from rotten banana fruits and they can withstand high alcohol content and low $\mathrm{pH}$. Furthermore, the rotten banana fruits regarded as wastes can be a useful raw material for the isolation of Acetobacter aceti needed for the industrial production of acetic acid and vinegar.

\section{REFERENCES}

[1] P. Giudici, G. Rinaldi. A theoretical model to predict the age of traditional balsamic vinegar. Journal of Food Engineering, Vol. 82, No. 2, 121-127, 2007. DOI:10.1016/j.jfoodeng.2007 .01 .014 . 
[2] M.J.R. Nout. Fungal interactions in food fermentations. Canadian Journal of Botany, Vol.73, No.51, 1291-1300, 1995. DOI: $10.1139 / \mathrm{b} 95-390$.

[3] P. Fellows. Food Processing Technology, Principles and Practice. VCH Publishers, UK, Vol. 9, 449-465, 2002.

[4] M. Gullo, P. Giudici. Acetic acid bacteria in traditional balsamic vinegar: Phenotypic traits relevant for starter cultures selection International Journal of Food Microbiology, Vol. 125, No.1, 46-53, 2008. www. sciencedirect.com/scienc e/article/pii/S0168160507006666.

[5] E.C. IIha, E. Sant' Anna, R.C. Torres, A.C. Port, E.M. Meinert. Utilization of Bee (Apis mellifera) honey for vinegar production at laboratory scale. Acta Cientifica Venezolana, Vol. 51, No.4, 231-235, 2000. http://www.researchgate.net/p ublication/1188051.

[6] S.K. Sossou, Y. Ameyapoh, S.D. Karou, C. DeSouza. Study of Pineapple peelings processing into vinegar by biotechnology. Pakistan Journal of Biological Science, Vol. 12, No. 11, 859-865, 2009. www.ncbi.nlm.nih.gov/pubmed/19803120.

[7] G. Ottogalli, A. Galli. Fermented foods in the past and in the future. Annali di Microbiologia ed. enzimologia, Vol. 47, No. 2, 100-115, 1997. http://agris.fao.org/openagris/search.do? record ID=IT1998061587.

[8] T. Kadere, T. Miyamoto, R.K. Oniano, P.M. Kutima, S.M. Njoroge. Isolation and identification of the genera Acetobacter and Gluconobacter in coconut toddy (mnazi). African Journal of Biotechnology, Vol.7, No. 16, 2963-2971, 2008. http://www.researchgate.net.publication/228689108.

[9] P.M. Falcone, P. Giudici. Molecular size and molecular size distribution affecting traditional balsamic vinegar aging. Journal of Agricultural and Food Chemistry, Vol. 56, No. 16, 7057-7066, 2008. DOI: 10.1021/jf800706g.

[10] B. Ndoye, I. Cleanwerck, K. Engelbeen, R. Dubois-Dauphin, A.T. Guiro, S.V. Trappen, A. Willems, P. Thonart. Acetobacter senegalensis sp nov., a thermotolerant acetic acid bacterium isolated in Senegal (Sub-Saharan Africa) from mango fruit (Mangifera Indica L.). International Journal of Systematic and Evolutionary Microbiology, Vol.57, No.7, 1576-1581, 2007. DOI:10.1099/ijs.0.64678-0.

[11] R.K. Hommel, P. Ahnert. Acetobacter In: Encylopedia of Food Microbiology, Academic Press, Volume 1, 352-359, 1999.
[12] W.J. Du Toit, M.G. Lambrechts. The enumeration and identification of acetic acid bacteria from South African red wine fermentations. International Journal of Food Microbiology, Vol. 74, No. 1-2, 57-64, 2002. DOI: 10.1016/S0168-1605 (10)00715-2.

[13] S.Onuorah, I. Obika. Bacterial Contamination of Used Manual Toothbrushes Obtained From Some Students of Nnamdi Azikiwe University Awka, Nigeria. Universal Journal of Microbiology Research, Vol. 3, No. 4, 56-59, 2015. DOI: 10. 13189.ujmr.2015.030404.

[14] J.G. Holt, N.R. Krieg, P.H.A. Sneath, T.W. Staley. Bergey's Manual of Determinative Bacteriology, $9^{\text {th }}$ ed. Williams and Wilkins, New York, U.S.A. Pp.817-825, 1994.

[15] J. Hickey-Richard, H. Vaughn-Reese. Industrial Fermentation: Chemical Publishing Co. Inc. New York, Chapter 17, Volume 1, 498-535, 1954.

[16] N. Okafor. Microbiology and biochemistry of oil-palm wine. Advances in Applied Microbiology, vol. 24, 237-256, 1978. www.sciencedirect.com/science/article/pii/S0065216408706 427.

[17] S.I. Faparusi, O. Bassir. Factors affecting palm wine. Period of tapping. West African Journal of Biological and Applied Chemistry, Vol. 15, No. 24, 32, 1972. www. Sciepub.com/reference/80294.

[18] V.I. Stainer. Acetobacter. Journal of Bacteriology, Vol. 54, $191,1947$.

[19] G.S. Drysdale, G.H. Fleet. Acetic acid bacteria in Some Australian Wines. Food Technology Australia, Vol. 37, 17-20, 1985. http://www.scopus.com/record/display.uri?eid=2-.

[20] S.P. Ukwo, C.F. Ezeama, N.U. Ndaeyo. Growth of different yeast strain during fermentation of Soursop (Annona muricata) juice as influenced by Acetic acid bacteria (Acetobacter aceti). Nature and Science, Vol. 8, No.10, 285-291, 2010. www.sciencepub.net/nature/ns0810.

[21] G.S. Kocher, K.L. Kalra, R.P. Phutela. Comparative production of Sugarcane vinegar by different immobilization techniques. Journal of the Institute of Brewing, Vol. 112, No.3, 264-266, 2006. DOI:10.1002/j-2050-0416.2006.tb007 22. $\mathrm{x}$ 